\title{
CONSTRUCTING AND PROMOTING NATIONAL IDENTITY THROUGH TOURISM: A MULTIMODAL DISCOURSE ANALYSIS OF INDONESIAN OFFICIAL TOURISM WEBSITE
}

\author{
Bayu Permana Sukma \\ Badan Pengembangan dan Pembinaan Bahasa \\ bayu.permana@kemdikbud.go.id
}

\begin{abstract}
Abs tract
This paper aims to examine the contribution of multimodal resources in the Indonesian official tourism website in constructing and promoting the Indonesian national identity. Data were gathered from 7 verbal (linguistic) texts and 13 visual (nonlinguistic) texts presented in the Indonesian official tourism website. This study draws on Wodak et al's (2009) discursive strategies of national identity construction and Kress and van Leuween's (2006) theory of visual design. The results of the study show that the combination of verbal and visual texts in the Indonesian official touris m website contribute to the Indonesian national identity construction and promotion. The constructed and promoted Indonesian national identity is: 1) Indonesia as a country with the rich natural landscape; 2) Indonesia as an archipelagic tropical country; 3) Indonesia as a maritime country; 4) Indonesia as a technologically advanced country; 5) Indonesia as a modern country; 6) Indonesia as a multicultural country; 7) Indonesia as a country with cultural richness; 8) Indonesians as people who are open to strangers or foreigners; 9) Indonesians as kind and friendly people; and 10) Indonesians as modern people. In addition, in terms of the visual texts, it is recommended that the cultural dimension of national identity be represented narratively in order to make a strong impression on the viewers, in that the dimension is more dynamic and is very close to human beings.
\end{abstract}

Keywords: national identity, official touris mwebs ite, multimodal dis course analy sis

\begin{abstract}
Abstrak
Makalah ini bertujuan untuk mengkaji bagaimana sumber-sumber multimodal pada laman resmi pariwisata Indonesia berkontribusi terhadap konstruksi dan promosi identitas nasional Indonesia. Data dalam penelitian ini diperoleh dari 7 teks verbal (linguistik) dan 13 teks visual (nonlinguistik) yang ditemukan pada laman resmi pariwisata Indonesia. Penelitian ini menggunakan teori strategi diskursif konstruksi identitas dari Wodak dkk (2009) dan teori desain visual dari Kress dan van Leuween (2006). Hasil penelitian menunjukkan bahwa kombinasi antara teks verbal dan teks visual pada laman resmi pariwisata Indonesia berkontribusi pada konstruksi dan promosi identitas nasional Indonesia. Identitas-identitas yang dikonstruksi dan dipromosikan tersebut antara lain: 1) Indonesia sebagai negara yang kaya akan sumberdaya alam;2) Indonesia sebagai negara kepulauan; 3) Indonesia sebagai negara maritim; 4) Indonesia sebagai negara berteknologi maju; 5) Indonesia sebagai negara maju; 6) Indonesia sebagai negara multikultur; 7) Indonesia sebagai negara yang kaya akan budaya; 8) masyarakat Indonesia sebagai masyarakat yang terbuka terhadap orang asing;9) masyarakat Indonesia sebagai masyarakat yang ramah; dan 10) masyarakat Indonesia sebagai masyarakatyang maju. Selain itu, terkait dengan teks visual pada laman, dimensi kultural dari identitas nasional sebaiknya direpresentasikan secara naratif untuk memberikan
\end{abstract}


kesan mendalam pada pembaca karena dimensi tersebut lebih dinamis dan berhubungan erat dengan manusia.

Kata kunci: identitas nasional, laman resmi pariwisata, analisis wacana multimodal

\section{INTRODUCTION}

Tourism has recently become a global huge industry. It now plays a significant role in the international economy, equalling other big businesses such as oil exports, food products, and automobiles (UNWTO, 2020). Thus, every country in the world attempts to get involved in a 'global competition' to promote themselves worldwide as tourism destinations by establishing tourism offices and creating tourism brands (Robinson \& Smith, 2006). To boost tourism promotion, each country also tries to explore its natural and cultural capital which shape and reflect on its national identity. Thus, national identity and tourism promotion are inseparable.

National identity is central to tourism promotion since it highlights the uniqueness of a country. By showing its uniqueness, a country emphasizes its differences from others. This attempt, in turn, will attract interested and curious foreign visitors to come and explore the beauty of, not only its nature but also its culture. While national identity contributes to tourism promotion, tourism promotion at the same time helps construct and promote national identity. In other words, tourism and national identity form a dialectical relationship, since the discourse of tourism constitutes national identity and the national identity is constituted or strengthened by the discourse of tourism as discourse is both constitutive (socially shaping) and constituted (socially shaped) (Fairclough, 1995; Jorgensen \& Phillips, 2002).

As the world entered the age of information, tourism promotion changed. It is no longer carried out through traditional print media. Instead, it is now done through websites. Becoming an effective medium of promotion, it enables potential tourists to virtually visit a destination and access information regarding the place prior to their physical tours (Hallet \& Kaplan-Weinger, 2010). In fact, the tourism website is very interesting and attractive due to its interactivity, because of its nature which does not only inform but also represents and mediates (Hallet \& KaplanWeinger, 2010).

Multimodality researches on websites and social media have actually been largely conducted by researchers. Their studies encompassed several is sues such as website interactivity (Adami, 2014), website as cultural expressions (Pauwels, 2012), website as hypermodality (Lemke, 2002), website as professional and socio-cultural expressions (Kong, 2018), identity on social media (Aguirre \& Graham, 2015) and metonymic representations on social media (Koow uttayakorn, 2018). Their studies also vary in terms of website types, ranging from food blogs, NASA website, hospital website (homepages), and social media such as Facebook and Instagram. Meanwhile, multimodality on official tourism websites has specific ally been carried out by Hallet \& Kaplan-Weinger (2010), Nekic (2015), and Tamašauskaite (2017). Hallet \& Kaplan-Weinger (2010) examined the narrative of the nation on Baltic countries' (Lithuania, Latvia, and Estonia) official tourism websites. In the study, they analyzed how verbal and visual texts were employed to construct and promote independent identities of those countries after gaining their independence from the Soviet Union. Nekic (2015) carried out research on the use of multimodal resources on Croatian and Scottish tourism websites to reveal how they work in representing tourist activities. Finally, Tamašauskaite (2017) attempted to critically analyze the 
communication of Lithuania's official tourism website with the slogan 'Lithuania: real is beautiful' through textual and visual analysis.

Studies on multimodality particularly in the Indonesian context of tourism have also been investigated by Rachmawati \& Pitana (2018) and Ansori \& Taopan (2019). In their study of multimodality of a video entitled Sedekah Gunung Merapi 'Offering for Mount Merapi', Rachmaw ati \& Pitana (2018) investigated the role of local w isdom for carrying tourism promotion in the Boyolali Regency. Meanwhile, Ansori \& Taopan (2019) explored ideational and representational meaning in a promotional video entitled Wonderful Indonesia, a video officially produced by the Ministry of Tourism of the Republic of Indonesia. At the end of their study, they also presented the implication of multimodality on English Language Teaching (ELT) which benefits teaching ESP and vocational school. Thus, theirs are different from this present study in terms of the research objects.

Shortly speaking, this study is closely related to the ones conducted by Hallet and KaplanWeinger and Tamašauskaite as their studies examined the relations between tourism promotion and national identity construction. This study, however, also differs from theirs with regard to the object of the research since it aims to bring the issue of national identity construction and promotion to the Indonesian context, particularly the Indonesian official tourism website.

As to Indonesia, the issue of national identity is still relevant and signific ant because national identity is not only a matter of a country's independence period - how long a country experienced its freedom. While newly independent countries such as Lithuania, Latvia, and Estonia construct their national identities to define their independent identities after becoming free nations (Hallet \& Kaplan-Weinger, 2010), two countries with longer history of independence like Austria (Wodak, Cillia, Reisigl, \& Liebhart, 2009) and Singapore (Tann, 2010) still also do the same to maintain their national identities. Most importantly, as a country which comprises more than 300 ethnic groups and 718 regional languages reflecting its diversity, Indonesia still also needs to redefine its national identity which covers "its conception of its enduring characteristics and basic values; its strengths and weaknesses; its reputations and conditions of existence; its institutions and traditions; and its past history, current purposes, and future prospects" (Kelman, 1997, p. 171).

To sum up, based on the aforementioned backgrounds, two research questions are proposed in this paper: (1) How are multimodal resources in the Indonesian official tourism website constructing and promoting the Indonesian national identity? and (2) What identity is constructed and promoted by the website? Thus, this study attempts to shed light on the relations between the use of verbal and visual texts on the website and the national identity construction and promotion.

\section{THEORETICAL REVIEW}

Multimodality refers to a meaning-making process through the use of various modes such as "image, writing, layout, music, gesture, speech, moving image, soundtrack, and 3D objects" (Kress, 2010, p.79). Thus, multimodal discourse analysis is to do with the analysis of discourse in multiple semiotic resources (Paltridge, 2008; O'Halloran, 2011). This framework is now largely applied in various discourse genres, ranging from print, dynamic, or static electronic media, to three-dimensional objects in space (O'Halloran, 2011, p.1). Multimodal analysis towards a website, as one of the products of electronic media, becomes significant since it is 
configured by several semiotic compositions such as linguistic and nonlinguistic texts (image, symbol, color), layout, etc. By applying the framework, the website produc er's intended meanings and communicative purposes can be revealed.

Several approaches for analyzing multimodal resources are proposed by some scholars. One of the applicable ones is outlined by Kress \& van Leeuwen (2006) which derive from Halliday's work on language as social semiotics. Adopting Halliday's concept of language metafunctions e.g., "ideational", "interpersonal", and "textual", they formulate three grand notions used in the visual-communication analysis, i.e., "representational", "interactive", and "compositional".

Table 1: Kress \& van Leeuwen's (2006) Theory of Grammar of Visual Design (summarizedfrom Kress \& van Leeuwen's (2006) and van Leeuwen \& Jewitt (2004))

\begin{tabular}{|c|c|c|c|}
\hline No. & Notions & Subcategories & Realizations \\
\hline \multirow[t]{2}{*}{1} & Representational & Narrative repres entation & $\begin{array}{l}\text { The use of vector connecting } \\
\text { two participants in image }\end{array}$ \\
\hline & & Conceptual repres entation & $\begin{array}{l}\text { Vis ually defining, analyzing, } \\
\text { clas sifying people, places, and } \\
\text { things }\end{array}$ \\
\hline \multirow[t]{3}{*}{2} & Interactive & Contact & $\begin{array}{l}\text { The way of the subjects looks } \\
\text { at the viewers: direct } \\
\text { (demanding) or indirect } \\
\text { (offering) }\end{array}$ \\
\hline & & Distance & $\begin{array}{l}\text { Size of frame of shots: close or } \\
\text { long shots }\end{array}$ \\
\hline & & Point of view & $\begin{array}{l}\text { The angle of shots: high level, } \\
\text { eye level, or low level }\end{array}$ \\
\hline \multirow[t]{4}{*}{3} & Compositional & Information value & $\begin{array}{l}\text { The placement of the elements } \\
\text { of a composition }\end{array}$ \\
\hline & & Framing & $\begin{array}{l}\text { Connecting and disconnecting } \\
\text { elements }\end{array}$ \\
\hline & & Salience & $\begin{array}{l}\text { The way of the elements is } \\
\text { made eye-catching through } \\
\text { size, color, etc. }\end{array}$ \\
\hline & & Modality & $\begin{array}{l}\text { The value of reality of the } \\
\text { image: abstract or concrete }\end{array}$ \\
\hline
\end{tabular}

While the representational meaning is based on the ideational metafunction, interactive meaning refers to the interpersonal metafunction, and compositional meaning derives from the textual metafunction. Representational meaning then covers narrative and conceptual structures; interactive meaning comprises some aspects: contact, distance, and point of view; and compositional meaning falls into categories: information value, framing, salience, and modality. Those three notions with their subcategories are useful for analyzing visual designs since they provide a set of practical analyzing tools in understanding meanings lying behind semiotic resources, especially images presented on a website. In the tourism promotional website examined in this study, the interactive and the compositional aspects hold a more vital role in the images 
presented on the website since they mostly involve in attaining the text producer's communicative goal.

Apart from the analysis of visual texts, the analysis of verbal texts is also significant in examining the present website. As the linguistic texts are not directly attached to the images presented, it is necessary to examine them separately utilizing a model of discursive strategies that are specifically related to the national identity construction. In that sense, Wodak et al's (2009) model of discursive strategies can be employed for the analysis. They suggest that there are five discursive strategies of national identity construction i.e., 1) Strategies of Justification and Relativisation, 2) Constructive Strategies, 3) Strategies of Perpetuation, 4) Strategies of Transformation, and 4) Strategies of Demontage (or Dismantling) and Destruction. Although those five strategies are very close to political discourse, they can also be found in tourism discourse (see Hallet \& Kaplan-Weinger, 2010). In the promotional tourism website, the strategies help to uncover the constructed national identity through the use of linguistic texts.

\section{RESEARCH METHOD}

Data for this study were collected from the Indonesian official tourism website (https://www.indonesia.travel/gb/en), which is officially managed by the Indonesian Ministry of Tourism, from January to February 2020. The website was chosen since it reflects the Indonesian government's visions in advancing Indonesian tourism industries.

There are actually two versions of the websites: Indonesian and English. The websites differ not only in their language of instructions but also in their contents. The Indonesian version targets domestic tourists while the English one is more foreign-visitor-oriented. For the purpose of this study, the data were collected from the English-version website. It was chosen since its potential users are foreign tourists. Therefore, it potentially reflects how Indonesia constructs its national identity and promotes it to the international community.

Data collected were 7 verbal texts and 13 visual texts. Out of four main menus on the website, i. e. 'What to See', 'What to Do', 'Plan Your Trip', and 'Go Explore', only data from 'What to Do', particularly submenu ' 5 Wonders' were collected. The reason is that the submenu more completely presents Indonesian tourism destinations and attractions. Verbal texts were taken from descriptions or explanations of destination highlights and attractions, and 'prologues' of each submenu 'Experience 5 Wonders' under the main menu 'What to Do'. As to the visual texts, those which were analyzed were merely 13 photographs in 'What to Do' menu. The photographs were chosen due to their function as a representation of each submenus, i.e., Nature, Scenic Landscape \& Wildlife, Culinary \& Wellness, Arts, Culture \& Heritage, Recreation \& Leisure, and Adventures.

After collecting the data, those which are verbal or linguistic texts were analyzed by using Wodak et al.'s (2009) approach of national identity discursive construction. The data were identified based on Wodak et al.'s categorization of discursive strategies of national identity construction. Meanwhile, visual or nonlinguistic texts were analyzed by using Kress \& van Leeuwen's (2006) theory of visual grammar. The analysis generally covered several aspects in terms of representational, interactive, and compositional meanings (Kress \& van Leeuwen, 2006). Those aspects were then analyzed in relation to national identity construction and promotion. 


\section{FINDINGS AND DISCUSSION}

\section{National Identity Construction and Promotion through Verbal Texts}

It is found that out of five discursive strategies of national identity construction proposed by Wodak et al. (2009), there is only one strategy used on the website, i.e. "Strategies of Perpetuation", particularly "Positive Self-Presentation" (summarized in Table 1). The finding could reflect the difference betw een political discourse and tourism discourse.

Table 2. Discursive Strategies of National Identity Construction on the Indonesian Official Tourism Website

\begin{tabular}{|c|c|c|c|}
\hline No. & $\begin{array}{l}\text { Discursive } \\
\text { Strategies of } \\
\text { National Identity } \\
\text { Construction } \\
\end{array}$ & Verbal Text & $\begin{array}{l}\text { Cons tructedand Promoted } \\
\text { National Identity }\end{array}$ \\
\hline 1 & $\begin{array}{l}\text { Perpetuation and } \\
\text { Positive Self- } \\
\text { presentation }\end{array}$ & $\begin{array}{l}\text { Extract } 1 \\
\text { "Having stopover in myriad places in } \\
\text { Indonesia is what makes this country a } \\
\text { wonderful place to visit. The beauty of } \\
\text { scenic natural landscapes blended with } \\
\text { various unique culture of its people. } \\
\text { Enjoy the untouched beaches, } \\
\text { mountains, lakes, and many more } \\
\text { pleasing destinations as well as the } \\
\text { magnificent city skylines throughout the } \\
\text { country. And when you decide to see } \\
\text { them all, a visit won't be enough to } \\
\text { embrace the wonders of Indonesia." }\end{array}$ & $\begin{array}{l}\text { Indonesia is a country with rich } \\
\text { natural landscape } \\
\text { Indonesia is a maritime country } \\
\text { Indonesian people are open to } \\
\text { strangers or foreigners }\end{array}$ \\
\hline 2 & & $\begin{array}{l}\text { Extract } 2 \\
\text { "Holiday with family brings much more } \\
\text { joy than a loner, and we are aware of it. } \\
\text { Therefore, to make sure yourfamily and } \\
\text { you have the most exciting experience, } \\
\text { Indonesia provides the best attractions in } \\
\text { the country. Let the kids running around } \\
\text { our great theme parks. Courage yourself } \\
\text { to explore rivers to get the most thrilling } \\
\text { rafting experience. To sum it up, we } \\
\text { have all the attractions to keep you } \\
\text { entertained." }\end{array}$ & $\begin{array}{l}\text { Indonesia is a country with rich } \\
\text { natural landscape } \\
\text { Indonesian people are kind and } \\
\text { friendly }\end{array}$ \\
\hline 3 & & $\begin{array}{l}\text { Extract } 3 \\
\text { "In this tropical country, explore the } \\
\text { magnificent white sandy beaches, great } \\
\text { volcanoes or colourful marine treasures. } \\
\text { One lifetime would not be enough to } \\
\text { explore Indonesia's naturalwonders." }\end{array}$ & $\begin{array}{l}\text { Indonesia is a country with rich } \\
\text { natural landscape } \\
\text { Indonesia is an archipelagic } \\
\text { tropical country } \\
\text { Indonesia is a maritime country }\end{array}$ \\
\hline
\end{tabular}




\begin{tabular}{|c|c|c|}
\hline 4 & $\begin{array}{l}\text { Extract } 4 \\
\text { "A nation is often measured by how } \\
\text { advanced its technology is Indonesia's } \\
\text { major cities adopt modern lifestyle that } \\
\text { is complete with stunning skyscrapers, } \\
\text { vibrant nightlife and technologically } \\
\text { advanced offices }\end{array}$ & $\begin{array}{l}\text { Indonesia is a technologically } \\
\text { advanced country } \\
\text { Indonesia is a modern country } \\
\text { Indonesian people adopt } \\
\text { modern lifestyle }\end{array}$ \\
\hline 5 & $\begin{array}{l}\text { Extract } 5 \\
\text { "Indonesia is a huge nation comprised } \\
\text { of hundreds of cultures derived from } \\
\text { local regions, making it one of the most } \\
\text { diverse countries in the world. Explore } \\
\text { the unique culture and heritage of each } \\
\text { region in Indonesia!" }\end{array}$ & $\begin{array}{l}\text { Indonesia is a multicultural } \\
\text { country } \\
\text { Indonesia is a country with } \\
\text { cultural richness }\end{array}$ \\
\hline 6 & $\begin{array}{l}\text { Extract } 6 \\
\text { "This is where to spoil your senses: } \\
\text { hearing, sight, touch, smell and taste. } \\
\text { Explore the many flavours Indonesia } \\
\text { has to offer by taking a bite out of some } \\
\text { local delicacies or delighting in } \\
\text { traditionalspa treatments." }\end{array}$ & $\begin{array}{l}\text { Indonesia is a country with } \\
\text { cultural richness }\end{array}$ \\
\hline 7 & $\begin{array}{l}\text { Extract } 7 \\
\text { "One would never get bored exploring } \\
\text { Indonesia. Plunge into thrilling caving } \\
\text { adventures, exotic diving escapades, } \\
\text { challenging volcano climbs, intriguing } \\
\text { jungle treks and many more!” }\end{array}$ & $\begin{array}{l}\text { Indonesia is a country with rich } \\
\text { natural landscape }\end{array}$ \\
\hline
\end{tabular}

"Strategies of Perpetuation" ("Positive Self-Presentation") on the website are generally used to create positive identities of Indonesia as a country, as shown in Table 1 (those identities could be categorized under Guibernau's (2004) two of five dimensions of national identity, i.e. "cultural" and "territorial" (or "natural") dimensions. Those identities are different from what the Baltic countries' official tourism websites try to predominantly construct, whichis an independent identity (Hallet \& Kaplan-Weinger, 2010). This could be motivated by the different history, sociopolitical and socio-cultural conditions of Indonesia and the Baltic countries. The predominant occurrences of the "positive self-presentation" on the verbal texts reflect the nature of the tourism website as an advertising genre (Michelson \& Valencia, 2016) and as a means to control impressions (Dominick, 1999) and to present a country to the international community (Mohammed, 2004). Thus, as a promotional medium, it uses words representing positive images of Indonesia as a world-class tourism destination.

It is also interesting that Wodak et al's (2009) another discursive strategy, i.e. "Demontage, Dismantling and Discrediting", is not found in the extracts while it occurs on the three Baltic countries' tourism websites (Hallet \& Kaplan-Weinger, 2010). It can be assumed that Dutch colonization is no longer relevant to Indonesia since it has already been an independent 
country for 74 years. That is to say, as a relatively-long independent nation, its biggest enemy is now its self. Conversely, reminiscing about Soviet occupation seems to be still important to Latvia and Estonia in order to construct their new identities as independent nations.

Those verbal texts' attempt to construct and to promote Indonesian national identity is in line with the way of visual texts work, as elaborated in the following subsection, in which both multimodal resources work together to construct Indonesian national identity. In other words, they both w ork collaboratively by strengthening each other to create meanings.

\section{National Identity Construction and Promotion through Visual Texts}

Regarding the visual texts, the findings will be discussed under the following subsections. The subsections are derived from the website's submenus, i.e., Nature, Scenic Landscape \& Wildlife; Culinary \& Wellness; Arts, Culture \& Heritage; Recreation \& Leisure; and Adventures.

\section{Nature, Scenic Landscape, and Wildlife}

Although depicting various objects, Figure 1, Figure 2, and Figure 3 generally try to capture the beauty of the natural landscape. Figure 1 depicts a sand island with scattered huge rocks, surrounded by turquoise-blue sea. On the island, there are several people enjoying the island. Figure 2 depicts a group of curvy mountains with an ac tive volcano on the left, the highest volc ano on the back and the center of the picture. Meanwhile, Figure 3 depicts curvy hills on the island surrounded by turquoise-blue sea. Those three figures deliver conceptual meaning as they represent "stable and timeless essence" instead of action or event (Kress \& van Leeuwen, 2006, p. 59). In terms of their interactive meaning, they do not intend to create a close relationship with the view ers since they make "offering" contacts and are captured in a long shot. In that sense, they suggest the viewers see them merely as objects.

Figure 1. Sand Is land with giant rocks

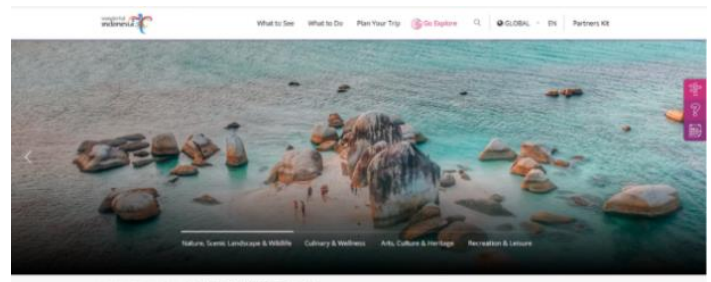

Figure 2. Curvy mountains

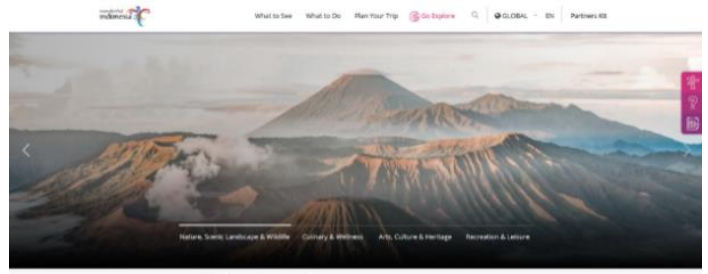

Figure 3. Curvy hills

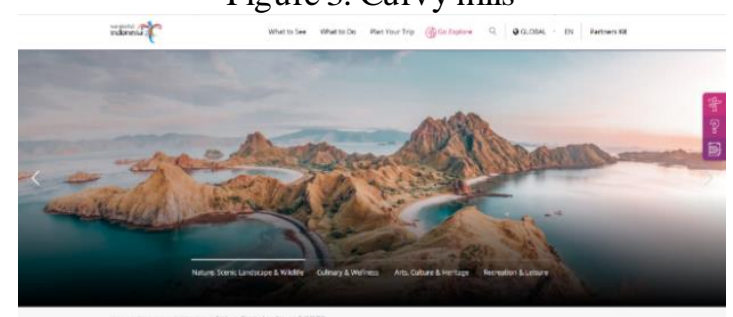

(https://www.indonesia.travel/gb/en/experience/experience-the-natural-wonders-of-indonesia)

The position in which the pictures place the objects, i.e., in the center of the frames, reveals that the objects are the most important or salient thing in the visual texts. While the 
salience in Figure 1 is the huge rocks, the salience in Figure 2 and Figure 3 are curvy mountains and curvy hills. In other words, it discloses that the huge rocks, curvy mountains and volcano, and curvy hills 'create a hierarchy of importance among the elements' (Kress \& van Leeuwen, 2006, p. 201). The way how objects are captured and positioned in those pictures is in line with Tamašauskaitè's (2017) study on Lithuania's official website where natural landscapes are represented for tourism promotion.

Moreover, the salient features of the pictures, e.g. natural landscapes (represented by rocks, mountains, and hills) play vital roles as visual metaphors since they should be looked 'beyond literal' in order "to generate...deeper levels of meaning" (Feinstein, 1982). The depiction of giant rocks, mountains, and hills could then metaphorize "longevity, strength, and power" of a nation (Hallet \& Kaplan-Weinger, 2010). Thus, the three pictures try to construct the Indonesian national identity as a strong and endured country.

\section{Culinary \& Wellness}

Three pictures represent "Culinary \& Wellness" on the website. Two pictures (Figure 4 and 6) specifically depict two Indonesian most-popular traditional cuisines, i.e., "satay" and "rendang". Meanwhile, the other portrays a living object, i.e., a lady practicing yoga. Figure 4 and Figure 6 clearly represent the submenu's title "culinary", while a lady practicing yoga is the representation "w ellness", which can be understood as a representation of health tourism.

Objects in Figure 4 and Figure 6 are captured in close-up shot, meaning that they try to create close distance with the viewers and thus invite them to observe. By taking the pictures from the top part, the author of the pictures attempts to make the view ers imagine themselves observing the reality (the cuisine) (Dallyono \& Sukyadi, 2019) and about to taste it. Meanwhile, in Figure 5 , the salient object (represented by a lady) is portrayed in medium shot. However, one can still see her facial expression, e.g. smiling, which shows her attempt to invite the view ers "to enter into a relation of social affinity with" her (Kress \& van Leeuwen, 2006, p. 118).

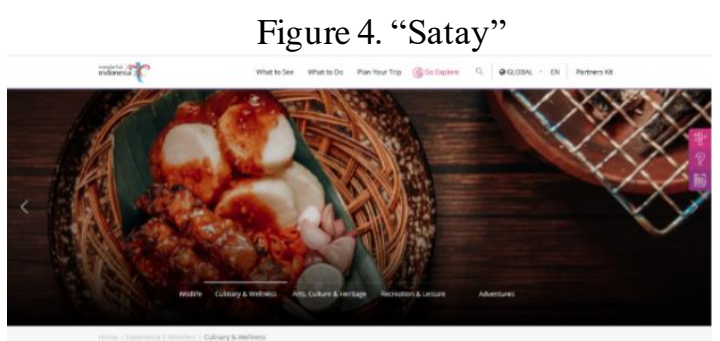

Figure 5. A Foreign Lady performing Yoga
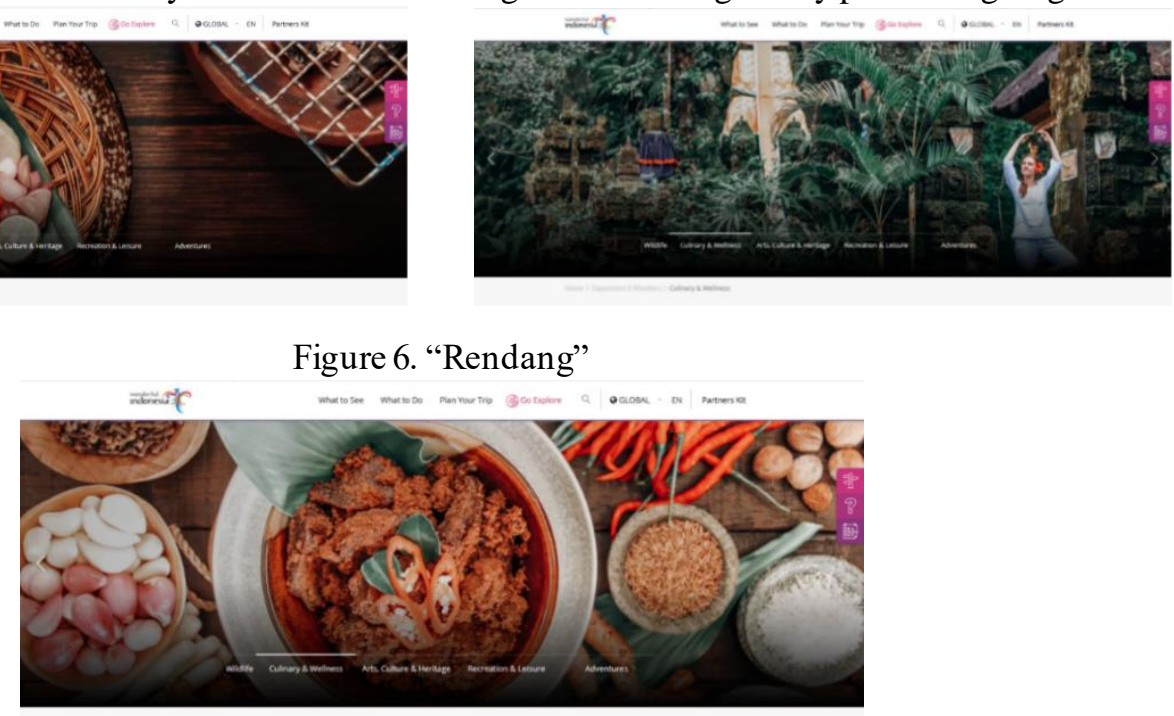

(https://www.indonesia.travel/gb/en/experience/experience-the-sensory-wonders-of-indonesia) 
In terms of the information value, that is how the objects are placed in the frames, the three Figures apply various ways. Figure 4 places the object on left, Figure 5 puts it on the right, while Figure 6 depicts its salient object in the center. It connotes that in Figure 4, the food ("satay"), as the 'given' element on the photograph is an Indonesian popular cuisine known worldwide. In Figure 5, the salient object on the right connotes that it is a "new" element. As the objects on the left ("given" elements) are predominantly green trees and stupas, it can be interpreted that situation in Indonesia, represented by natural (through green trees) and religious (through stupas) environment is supportive to the healthy life in general, and health tourism in particular. Meanwhile, in Figure 6 where the salient object is in the center of the frame, it can be assumed that the food ("rendang") is the most popular Indonesian cuisine. As the "rendang" is surrounded by spic es, it can be interpreted that "rendang" is made of various them. In other words, "rendang" in the picture denotes the core of information while the spices become its dependent elements (Kress \& van Leeuwen, 2006, p. 196).

The spices represented in Figure 6 also implicitly reveal that Indonesia possesses an abundance of spices, which became one of the reasons why western countries colonized the archipelago for centuries. In addition, the depiction of foreign lady practicing yoga can also convey two meanings. First, "the foreign lady" tells the viewers that Indonesia is open to foreigners, thus Indonesians are cosmopolitans. Second, yoga symbolizes spirituality and tranquillity, thus it attempts to tell the viewers that Indonesians are accustomed to spiritual activities that promote tranquility.

\section{Arts, Culture \& Heritage}

Arts, Culture \& Heritage are represented in Figures 7, 8, and 9. Arts are represented in Figure 7 through the depiction of some traditional dancers, "Culture" is represented in Figure 8 through the depiction of batik making, and "Heritage" is represented in Figure 9 through the depiction of Borobudur Temple.

Figure 7. Traditional dancers

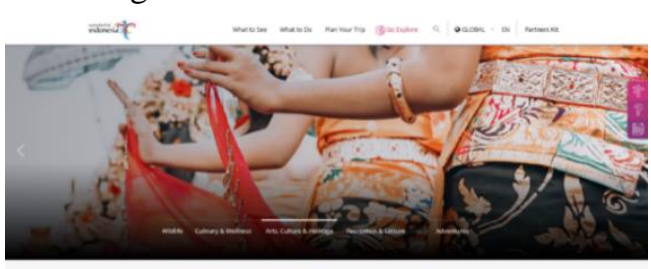

Figure 8. Batik making

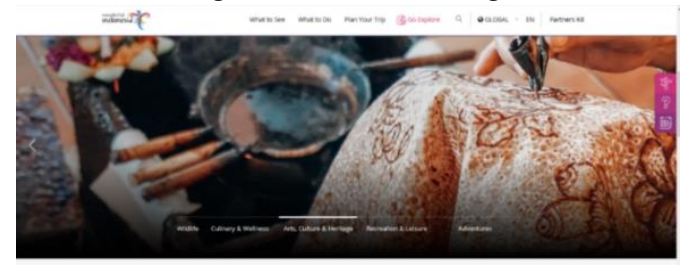

Figure 9. Borobudur Temple

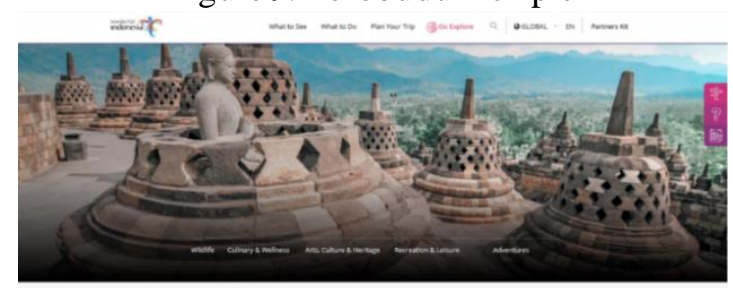

(https://www.indonesia.travel/gb/en/experience/experience-the-cultural-wonders-of-indonesia)

Figure 7 depicts three dancers performing Indonesian traditional dance taken from behind. Since the salient objects (the three dancers) are not trying to make any contact with the 
viewers, in this photograph, the viewers are positioned as observers. However, this angle can also position them as participants of the activity as if they were also part of the dancing group (Tamašauskaitè, 2017). As the consequences, they are then asked to engage and to participate "in the commemoration and maintenance of the tradition" (Hallet \& Kaplan-Weinger, 2010, p. 28).

In Figure 8, the viewers are also treated as observers of the batik making process. Batik painting process as the most salient feature in the photograph is placed on the right of frame and thus functions as "New" element. Meanwhile, the heated wax, as the material needed for the batik painting, is placed on the left of the frame, and thus serves as the "Given" element. Through the composition, the author presumably intends to deliver a message to the viewers that there are always hard works and uneasy processes behind every beauty of batik. In Figure 9, the salient object is the Budha statue which carries function as the "given" element. It suggests that Borobudur has already been popular worldwide as the largest Buddhist temple in the world while the forest, as "new" element in the picture, represents nature. The combination of the two elements implies the harmony of culture and nature. In addition, the Budha statue creates a vector line. The argument is also supported by the realization of the vector from the Budha statue to the forest.

\section{Recreation \& Leisure}

"Recreation \& Leisure" are represented in Figure 10 and Figure 11. This subcategory refers to shopping and contemporary-lifestyle tourism. While Figure 10 depic ts the skyscrapers, Figure 11 captures colorful batik fabrics. The depiction of skyscrapers in Figure 10 represents modernity. It could also metaphorize the modern lifestyle of the Indonesian people. Skyscrapers and high buildings are symbols of technological and economic advances; thus, the depiction also supports the verbal text (Extract 4). In addition, as Hallet \& Kaplan-Weinger (2010, p. 32) argue, skyscrapers which are made of steel and glass also symbolize "currency and openness", "reflection and transparency" - the ethos which should be possessed by modern people.

Figure 10. Skyscrapers

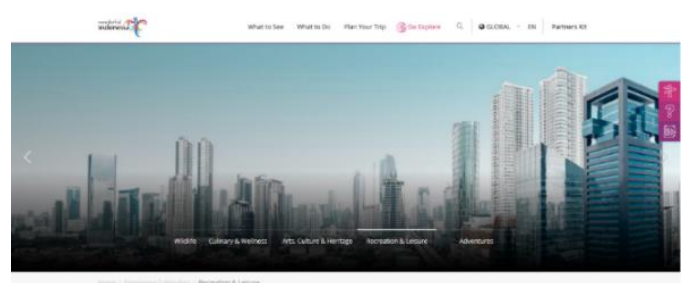

Figure 11. Batik

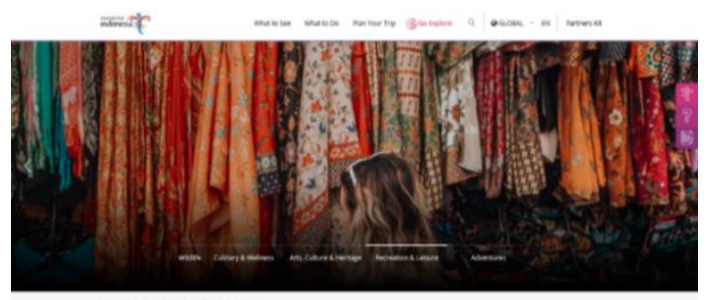

(https://www.indonesia.travel/gb/en/experience/experience-the-modern-wonders-of-indonesia)

Meanwhile, the depiction of colorful batik fabrics in Figure 11 metaphorizes Indonesia's multiculturalism (this is in line with the verbal text on Extract 5). The depiction represents how beauty and harmony are composed of differences, instead of sameness. The depiction of a woman in the center of the frame also helps to interpret the picture. As she is captured from behind and thus is not trying to make any contact, the view ers are asked to observe and gaze upon Indonesia's harmonious multiculturalism. 


\section{Adventures}

Submenu "Adventures" is represented by two photographs, e.g., Figure 12 and Figure 13. Both pictures specific ally portray an underwater view, suggesting that Indonesia is an archipelagic or maritime country since being surrounded by seas. Thus, those depictions support the verbal text (Extract 1,3,7).

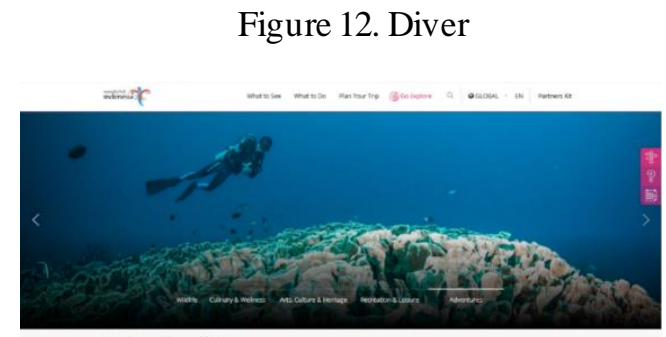

Figure 13. Sea turtle with diver

(https://www.indonesia.travel/gb/en/experience/experience-the-adventure-wonders-of-indonesia)

The two pictures differ only in the objects they represent. While in Figure 12 the representing objects are the diver and the reef, in Figure 13 the objects are the sea turtle and the diver. In terms of its informational value, the picture in Figure 12 can be investigated according to the position of the objects. Besides functioning as the "Given" element, the diver also serves as the "Ideal" because it is placed on the top (Kress \& van Leeuwen, 2006). Meanwhile, the reef functions as "New" element and "Real" due to its position on the bottom of the picture (Kress \& van Leeuwen, 2006). As Kress \& van Leeuwen (2006, p. 186-187) suggest, "Ideal" indicates that the object is "idealized or generalized essence of information" while "Real" is "more specific", "more down-to-earth", or "more practical". Thus, the "Real" serves to elaborate on the "Ideal". In the context of Figure 13, the reef is the elaborated information of the diver. Thus, it c an be interpreted that coral reefs are the offered attraction of underwater adventure.

In Figure 13, informational value is represented by the sea turtle whose role is "Given" while the diver occupies "New" element. There is no "Ideal-Real" structure prevailing in this picture as both objects form a horizontally parallel line. As the "Given" element, the depiction of sea turtle tries to convey a message that sea turtle is sea species easily found in Indonesia's seas (there are six species of sea turtle living in Indonesia's seas: "Caretta caretta", "Chelonia mydas", "Lepidochelys olivacea", "Dermochelis coriacea", "Eretmochelys imbric ate", "Natator depressa" (pesona.travel, 2020)). Meanwhile, the depiction of the diver which functions as the "New" element implies that tourist who is represented by the diver holds a significant role in sea turtle conservation in particular and Indonesia's natural environment in general. This is supported by the "interactional process" created by a vector formed by eye direction (Kress \& van Leeuwen, 2006; Oyebode \& Unuabonah, 2013; Ananda, Fitriani, Samad, \& Patak, 2019) of the sea turtle and the diver.

\section{CONCLUSION}

This study reveals that multimodal resources are employed on the Indonesian official tourism website to construct and to promote Indonesian national identity. Although the verbal texts are not directly attached to the visual presentations, or in other words not directly forming the textimage relationship, the two resources still indirectly work in a collaborative way to make meanings. 
The analysis of the verbal texts shows that a discursive strategy of "perpetuation and positive self-presentation" is used to construct and to promote Indonesian national identity. The constructed and promoted national identity is: 1) Indonesia as a country with rich natural landscape; 2) Indonesia as an archipelagic tropical country; 3) Indonesia as a maritime country; 4) Indonesia as a technologically advanced country; 5) Indonesia as a modern country; 6) Indonesia as a multicultural country; 7) Indonesia as a country with cultural richness; 8) Indonesians as people who are open to strangers or foreigners; 9) Indonesians as kind and friendly people; and 10) Indonesians as modern people.

Those constructed identities are supported by the result of the analysis of the visual texts representing the five wonders of Indonesia promoted on the website, i.e., Nature, Scenic Landscape \& Wildlife, Culinary \& Wellness, Arts, Culture \& Heritage, Recreation \& Leisure, and Adventures. The analysis of representational, interactive, and compositional aspects of the visual presentations strengthens the potential meanings which the website tries to communicate in the verbal texts. In addition, as the conceptual representations are predominantly found in the visual texts for representing both natural and cultural dimension of national identity, it is recommended that the narrative representations be used more for cultural one. It will potentially make a strong impression on the viewers since the cultural dimension is more dynamic and is very close to human beings.

This study, however, has a limitation as it involves more the researcher's interpretations of the data, though supported by linguistic theories and literature. Thus, future research, if possible is encouraged to add interview and survey data obtained from the website designer as text producer and the website users as text consumers. This will help make the research more justifiable and verifiable since some argue that the aim of multimodal discourse analysis is not only to inquire into "meanings" behind the multimodal resources but also to look into their "effects" on society, as 'discourse is not only constituted but also constitutive'. Moreover, since this study only covered verbal and visual data acquired from one main menu on the website, it is recommended that future research analyze the other menus to get a bigger picture of the relationship between the national identity construction and promotion and the Indonesian official tourism website. It is also recommended that the future study investigating the other south-east Asian countries' official tourism websites be conducted since it will be interesting to compare the ways of ASEAN countries constructing and promoting their national identities through their official tourism websites.

\section{NOTE}

The author would like to thank two anonymous reviewers and the committee of Seminar Nasional Linguistik dan Sastra (SEMANTIKS) 2020 for their very helpful comments on the earlier draft of thepaper.

\section{REFERENCES}

Adami, El. (2014). What's in a click? A social semiotic framework for the multimodal analysis of website interactivity. Visual Communication, 14(2), 133-153. https://doi.org/10.1177/1470357214565583 
Aguirre, A. C., \& Graham, S. (2015). Imperfect strangers: Picturing place, family, and migrant identity on Facebook. Discourse, Context and Media, 7, 3-17. https://doi.org/10.1016/j.dcm.2014.12.001

Ananda, R., Fitriani, S. S., Samad, I. A., \& Patak, A. A. (2019). Cigarette advertisements: A systemic functional grammar and multimodal analysis. Indonesian Journal of Applied Linguistics, 8(3), 616-626. https://doi.org/10.17509/ijal.v8i3.15261

Ansori, M., \& Taopan, L. L. (2019). A Multimodal Discourse of Promotional Video Wonderful Indonesia. Elite, 6(1), 1-18.

Dallyono, R., \& Sukyadi, D. (2019). An analysis of multimodal resources in environmental protection posters. Indonesian Journal of Applied Linguistics, 9(2), 472-479. https://doi.org/10.17509/ijal.v9i2.20245

Dominick, J. R. (1999). Who Do You Think You Are? Personal Home Pages and SelfPresentation on the World Wide Web. Journalism \& Mass Communication Quarterly, 76(4), 646--658. https://doi.org/10.1177/107769909907600403

Fairclough, N. (1995). Critical Discourse Analysis: The Critical Study of Language. New York: Longman.

Feinstein, H. (1982). Meaning and Visual metaphor. Studies in Art Education, 23(2), 45-55.

Guibernau, M. (2004). Anthony D . Smith on nations and national identity : a critical assessment. Nations and Nationalism, 10(1/2), 125-141.

Hallet, R. W., \& Kaplan-Weinger, J. (2010). Official Tourism Websites: A Discourse Analysis Perspective. Bristol: Channel View Publications.

Jorgensen, M., \& Phillips, L. J. (2002). Discourse Analysis as Theory and Method. London: SAGE Publications.

Kelman, H. C. (1997). Nationalism, Patriotism, and National Identity: Social-Psychological Dimensions. In D. Bar-Tal \& E. Staub (Eds.), Patriotism in the Lives of Individuals and Nations (pp. 165--189). Chicago: Nelson-Hall Publishers.

Kong, L. (2018). A Multimodal Analysis of Hospital Homepages. Advances in Social Science, Education and Humanities Reseacrh (ASSEHR), 228(Klua), 312-320.

Koow uttayakorn, S. (2018). An Investigation of Instagram's Metonymy : A Multimodal Social Semiotic Approach. LEARN Journal: Language Education and Acquisition Research Network Journa, 1(1), 140-149.

Kress, G. (2010). Multimodality: A Social Semiotic Approach to Contemporary Communication. New York: Routledge.

Kress, G., \& van Leeuwen, T. (2006). Reading Images: The Grammar of Visual Design. New York: Routledge.

Lemke, J. L. (2002). Travels in hypermodality. Visual Communication, 1(3), 299-325.

Michelson, K., \& Valencia, J. A. Á. (2016). Study Abroad : Tourism or education ? A multimodal social semiotic analysis of institutional discourses of a promotional website. Discourse \& Communication, 1--22. https://doi.org/10.1177/1750481315623893 
Mohammed, S. N. (2004). Self-presentation of small developing countries on the world wide web: a study of official websites, 6(4), 469-486. https://doi.org/10.1177/146144804044330

Nekic, M. (2015). Tourist Activities in Multimodal Texts An Analysis of Croatian and Scottish. New York: Palgrave Macmillan.

O’Halloran, K. L. (2011). Multimodal Discourse Analysis. In K. Hyland \& B. Paltridge (Eds.), Continuum Companion to Discourse Analysis (pp. 120--137). Chennai: Continuum.

Oyebode, O., \& Unuabonah, F. O. (2013). Coping with HIV / AIDS : A multimodal discourse analysis of selected HIV / AIDS posters in. Discourse \& Society, 24(8), 810--827. https://doi.org/10.1177/0957926513503269

Paltridge, B. (2008). Discourse Analysis: An Introduction. London: Continuum.

Pauwels, L. (2012). A Multimodal Framework for Analyzing Websites as Cultural Expressions, 17, 247-265. https://doi.org/10.1111/j.1083-6101.2012.01572.x

pesona.travel. (2020). Jenis-jenis Penyu yang ada di Indonesia. Retrieved March 5, 2020, from https://pesona.travel/keajaiban/5611/jenis-jenis-penyu-yang-ada-di-indonesia

Rachmawati, J. I., \& Pitana, T. S. (2018). Presenting Local Wisdom : A Multimodal Analysis of Sedekah Gunung Merapi Video as a Tourism Pro- motion in Boyolali Regency. Jurnal Komunikasi Indonesia, VII(3), 235-245.

Robinson, M., \& Smith, M. (2006). Politics, Power and Play: The Shifting Contexts of Cultural Tourism. In M. Smith \& M. Robinson (Eds.), Cultural Tourism in a Changing World: Politics, Participation and (Re)presentation (pp. 1--17). Clevedon: Channel View Public ations.

Tamašauskaitè, V. (2017). Critical Discourse Analysis of Lithuania's Official Tourism Communication. Radboud University Nijmegen.

Tann, K. (2010). Imagining Communities: A Multifunctional Approach to Identity Management in Texts. In M. Bednarek \& J. R. Martin (Eds.), New Discourse on Language (pp. 163194). London: Continuum.

UNWTO. (2020). Why Tourism? Retrieved February 11, 2020, from https://www.unwto.org/why-tourism

van Leeuwen, T., \& Jewitt, C. (2004). The Handbook of Visual Analysis. Cape Town: SAGE Public ations. https://doi.org/10.4135/9780857020062

Wodak, R., Cillia, R. De, Reisigl, M., \& Liebhart, K. (2009). The Discursive Construction of National Identity (Second). Edinburgh: Edinburgh University Press. 